\title{
Correction to: POWER: A Caregiver Implemented Mand Training Intervention
}

\author{
Meka N. McCammon ${ }^{1}$ (D) Katie Wolfe ${ }^{1} \cdot$ Kayla Zaluski $^{2}$ \\ Published online: 30 July 2021 \\ (C) Association for Behavior Analysis International 2021
}

\section{Correction to: Behav Analysis Practice.} https://doi.org/10.1007/s40617-021-00620-5

This article was updated to correct Katie Wolfe's name in the author listing.

Publisher's Note Springer Nature remains neutral with regard to jurisdictional claims in published maps and institutional affiliations.

The online version of the original article can be found at https://doi.org/ $10.1007 / \mathrm{s} 40617-021-00620-5$

$\triangle$ Meka N. McCammon mccammsn@email.sc.edu

1 Department of Educational Studies, University of South Carolina, 240 Wardlaw, 820 Main St, Columbia, SC 29208, USA

2 Sam Houston State University, The Woodlands, TX, USA 